\title{
Gaining Motivation on English Learning for Special Need Students Using Flashcards, Foldable Books and Posters in EFL Context
}

\author{
Suhartini Syukri ${ }^{1}$, Isna Humaera ${ }^{2}$ \\ 1nstitut Agama Islam Negeri Kendari, Indonesia. E-mail: suhartinisyukri@gmail.com \\ 2Institut Agama Islam Negeri Kendari, Indonesia. E-mail: humaeraumk@gmail.com
}

ARTICLE INFO
Keywords:
Foldable Books;
Flashcards; Motivation;
Posters; Special Needs
Student
How to cite:
Syukri, S., et al. (2019).
Gaining Motivation on
English Learning for
Special Need Students
Using Flashcards,
Foldable Books and
Posters in EFL Context.
Langkawi Journal of The
Association for Arabic and
English, 5(2), 91-101
DOI:
http:/ / dx.doi.org/10.31
332/lkw.v5i2.1303

\begin{abstract}
Teaching special needs students becomes more challenging and frustrating. Moreover, some SLB in Kendari nowadays have not been facilitated by suitable learning media, particularly in EFL context. This study describes the research that sought to understand if the teaching media electronic or not, using flashcards, foldable books, and posters, is under the necessities of deaf and hard hearing students. This question becomes the primary goal of the investigation, and its enlighten is divided into three specific goals. They are, finding out the effects of the media used in assisting special need students and EFL teacher in the class; helping them in communication and comprehending the teaching materials especially in vocabulary English class; and gaining EFL teacher's and special need students' motivation in teaching and learning process utilizing the media. This study used qualitative by single case study design, which was conducted about six months in 2018. Five students by deaf and hard hearing impairment of SLB-F Mandara (special private junior high school) are as the sample of this study. The observation list and depth-interview were utilized in data collection. After doing some interventions, the data analysis used data reduction, data display, and conclusion. The results showed that by intervention and utilizing diverse media by flashcards, foldable books and posters could ultimately gain teacher's and students' motivation in the EFL context.
\end{abstract}

\section{Introduction}

Teaching English for special needs of Junior School students is one of the compulsory subjects in Indonesia. Based on the curricular content, it focuses on the increasing students' basic competencies, which can achieve and comprehend simple vocabulary, greeting others, a compliment for the happiness, achievement, and functional text which are used in daily life, both in spoken and written (Dolorosa, 2016). However, in the school, the most problem shows that teacher, in facilitating students by the media teaching nowadays, seems less creative and limited to their allotted time. Teachers should be more focus on how to make the students understand about the content study while in the other sides, they are still difficult in communicating their mother tongue (own language, in this case, Bahasa Indonesia) so that teaching English becomes big challenging and trouble.

English for special need students is related to write in two ways; letter-sound correspondences which are students need to access sounds to know what letters stands for, and connection between oral and written English, Herrera-Fernandez, et al. (2014), since the school did not give any attentive caring toward the deaf students. The main 
problems of the situations are "communication and teaching media," then this study supposed to be very important to deal with the case and it strongly needs to help both students and teachers in enhancing their knowledge and building motivation in teaching and learning English for deaf and hard hearing students.

This issue requires full attention that teaching and learning English for them nowadays becomes challenging and sometimes frustrating. Teachers are demanded to have prominent competence in teaching English by diverse circumstances and handicapped. Here, an effective teacher or therapist can have a dramatic impact on a child's or student's educational progress and achievement (Lichtert et al., 2016, p.135). Similarly, various factors influence the professional's teacher effectiveness. Moreover, the National Council Accreditation of Teacher Education states that effective teaching, rehabilitating, or coaching families depends on having the essential knowledge and skills needed to work competently with the children, students, or families to whom they are assigned (2006).

Some rationales made the researcher enthusiastic about conducting this kind of research. Some of them are; 1) students' motivation and teacher's motivation were lack; it was based on the field observation and interview to the teacher and the students themselves; 2) teaching the disable or deaf and hard hearing students especially for EFL context seemed monotonous and 3) there was no media display in the classroom, especially such as ASL signs, flashcard, even a poster. The situation affected the atmosphere in the EFL class boring, and students became demotivated. They strongly need the appropriate media in considering their disabilities, and the media should have various models reflecting their simplicity and effectiveness.

Hence, this research attempts to respond how to help junior special students of deaf and hard hearing handicapped in EFL class, the effect of teaching media in assisting students and teachers in EFL class specifically for the deaf and hard hearing of junior special students of SLB-F Mandara and, to what extent is sign language and vocabularies in the flashcard significantly helped and understood by the deaf and hard hearing students in EFL context.

\section{Deaf and Hard Hearing Students in EFL Context}

In the EFL context, deaf and hard hearings are students' hearing impairments, which lead to linguistics problems. Difficulties manifest them to acquire the language well, then the English as the subject in the school becomes harder and harder. Listening for the deaf is speech reading/lip reading as a process of understanding spoken language through visual analysis of mouth and face movement. It is complicated and tiring. However, it is the most effective significant residual hearing (Lazanova, Slavina Boian \& Savtchev, 2009). The students must use speech reading to supplement visual speech reading. In this case, good lighting is vital. In addition, speaking for them is about pronunciation and voice, which means if they can hear their voice, they are unaware of the errors and articulation problems that will occur. Typical voice disorders include hoarseness, breathiness, or sudden breaks in loudness or pitch. Then, they do not mean a lot and contribute to students' verbal and non-verbal language.

Some previous researchers reported that English vocabulary development for deaf and hard hearing students is more slowly since they only find pictures and words as the symbols, then the rarely used of various media, which does not work. Generally, 
students tend to learn concrete words more easily rather than abstract words (Mpofu \& Chimhenga, 2013, p.1). Moreover, Hasstenteufel (2009) states that Deaf students and hard hearing students' characteristics in learning English are unable to comprehend the text in the form of interpersonal, transactional, functional text by a picture or without a picture or by directly explained, since to them, the meaning only by symbols concept. Thus, these rationales consider obtaining further overcoming problems in the EFL context.

\section{Motivation in Learning English as L2 for Deaf and Hard Hearing Students}

Learning English needs language aptitude in which the learner can vary in the rate they learn a second language and why some are successful and others not. It is believed to be in part related to general intelligence and part, distinct (Ellis, 1997). Here, language aptitude composes of different types of abilities: (1) The ability to identify and memorize new sounds; (2) the ability to understand the function of particular words in sentences; (3) the ability to figure out grammatical rules from language samples; and (4) memory for new words."

From some researches, it is found that students' high scores in language aptitude attain higher levels of proficiency than learners with a low score. Thus, it relates to the process of second language acquisition (Hasstenteufel, 2009, p.71). Besides the language aptitude, learner motivation has central importance. Motivation is the inner power that pushes someone toward taking action and toward achievement. It is a private student experience, one that is mostly invisible to the teacher needs to be inferred, such as behavioral engagement and emotional involvement powered by desire and ambition (Cheon \& Reeve, 2015, p.100). Therefore, if they are absent, motivation is absent too. Motivation can affect the initiative and direction, as well as courage, energy, and persistence to follow the teaching and learning goals. Language aptitudes concern the cognitive abilities that underlie successful L2 acquisition. Motivation involves attitudes and affective states that influence the degree of effort that learners make to learn an L2.

Various kinds of motivation have been identified. They are instrumental, integrative, resultative, and intrinsic (Ellis, 1997). Instrumental motivation is for functional reasons; in this case, what the target language's rationales to learn; Integrative motivation relates to those learners who want to feel integrated in the target-language group; Resultative motivation is seen as the motivation that results from learning; meanwhile Intrinsic motivation is maintained by the curiosity and the learner's particular interests that keep them personally involved in learning process. (Hasstenteufel, 2009). Another theory of motivation closely related concepts as pushpull theory, drive theory, expectancy-value theory, achievement theory, goal-setting theory, and self-determination theory (Saripah \& Syukri, 2017).

In such a situation of deaf and hard hearing students, the motivation will strongly need. The lack of motivation will bring demotivated, in case of students and teachers who are frustrated and difficulty in handling the class. Enhancing students by various media contribute them in building their confidence and motivation in English class. Media, as assistive technology, particularly visual technologies, should also be available for all deaf and hard hearing children and their families (Sass- Lehrer \& 
Young, 2016). Furthermore, technological innovations such as the Internet enables access to visual languages such as signed languages as never before.

Besides, adapting Novera and Andrews's theory, there are five basic principles of motivation exist that apply to learning in any situation; 1) The environment can be used to focus the student's attention on what needs to be learned; Interesting visual aids, such as booklets, posters, or practice equipment, motivate learners by capturing their attention and curiosity; 2) Incentives motivate learning, Incentives include privileges and receiving praise from the teachers, peers, and parents; 3) Internal motivation is longer lasting and more self-directive than is external motivation, which must be repeatedly reinforced by praise or concrete rewards; 4) Learning is most effective when an individual is ready to learn, that is when one wants to know something, and 5) Motivation is enhanced by how the instructional material is organized (Weller, 2005). Those basic principles can be applied for the students in EFL context to gain their motivation in learning English process.

Besides, media are varied and supported by way of teaching and how the media used more attracted for students, not only seen as the symbols as the most general assumption of students by loss hearing (Ghafoor, Ahmad, \& Huang, 2015). Language class, which integrated four skills of English as regular students demand, is not fully fulfilled by the deaf and hard hearing students. Still, motivation can cover them to increase students' knowledge in language skills and to make them understand more about English as foreign language and as the tool of communication (Stinson, Michael, Lisa, Elliot, \& Kelly, 2017). Flashcard, as the media teaching is a card with the tiny size and used by the students as strategy stipulate specific instructions to prosper comprehension skills, utilized visual aids (Razalli et al., 2018). It can be made easy by teachers or students to enrich their vocabulary.

\section{Method}

Knowing the students' motivation can be very simple and easy by asking students and teachers to interview. However, since the object of the study is the deaf students and hard hearing students, then this study turns to be trickier to accomplish. Thus, in designing the study, the researcher adopted a qualitative case study design, which was conducted about six months in 2018. The single case study typology was chosen to make an investigation carried out by classroom practitioners in a professional context. The population of this study is students at SLB-F Mandara at Junior High School level for the student with special needs. There were 4 (four) deaf students and 1 (one) hardhearing student disability as the main subject of the study. The subjects of the study were students' at the $8^{\text {th }}$ graders and $9^{\text {th }}$ graders by difference age but at the same level. A teacher with an English education study background was involved in teaching using flashcards. This kind of data was referred to as the social needs and interfered with by students' needs, moreover supported by the researcher and parents' contribution to making the complete package of treatment.

In collecting data, an English teacher in SLB-F Mandara Kendari has been purposively selected as the primary source. Discussions about the case have been done in terms of knowing the subject and field of study. It was recorded verbatim and then transcribed. Initially, the researcher collected the information through discussion and questionnaires about teachers' and students' motivation in English to design the 
appropriate media used in the classroom. The effects of media were justified after giving all kinds of media includes flashcards, and then supported by foldable books and posters.

In the treatment process, the researcher applied four stages in ABAB single case research design (Nunan, 1992). In analyzing the data, the theory of Miles and Huberman was used. The researcher described the data collected in more detail and concluding. In the process of concluding, data was confirmed by the result of the analysis theory taken from the motivation analysis theory of Ellis (1997) and Williams, Marion, Mercer, \& Ryan. (2015). Triangulation was a method used by qualitative researchers to check and establish validity in their studies. In this research, for enhancing the validity of the data, triangulation was done by crosschecking the two sources of data.

Hence, data analysis was obtained from a video recording, observation, documentation, and taking the conclusion. Firstly, students are asked by their English teacher for some questions (about students' motivation) utilizing video recording. The video used to read their lips-moving and gestures for further analysis. Observation used while learning process. It was conducted eight times while learning process. The documentation then completed the data collection to take the conclusion from all of the previous instruments used to be analyzed using motivation theory. The analysis was followed by grounded theory includes segmenting and arranging the data and generating them as completion of overcoming problems for teaching and learning process for deaf and hard-hearing students.

\section{Findings and Discussion}

This phase gives details about students' profiles and their language use, students' vocabulary development, and teacher strategies using posters, foldable books, and flashcards to enhance students' motivation in learning English.

\subsection{Students' Profile and their Language Use}

There are five students by deaf and hard-hearing impairment as the subject of this study. Each of them has its specific characteristics. One student is 17 years old, who studies in 9 graders (Student A). Four other students are in 8 graders (Student B is 16 years old, Student C is 15 years old, Student D is 14 years old, and Student E is 13 years old). They have different ages but at the same level of acquisition and study in one class. One of them was born as a deaf person, and four students are having hard hearing impairment also since they were born. One of the students (Student B) has double handicapped. He has deaf handicapped and physical handicapped.

For students' language use, in the first interview, the teacher was aware that her students mostly have a problem in their views on language use. They found difficulties in developing their English language since they hardly hear when other people are communicating. She emphasized her report that student B is the hardest one in learning English, even memorizing the word. However, the four students, on average, also had a lack of motivation in learning English. They assumed that English is a confusing term. In addition, most of them had not developed their vocabulary and easy to forget the words, even the words in their mother tongue (Indonesian).

According to the teacher, it needed about one year to adapt and adopt students' sign language. She should understand the context of students bring in their daily 
communication while they sometimes made their vernacular sign language as their style, not in the way of common appropriate sign language of Indonesian formal sign language. From 5 students, only one of the students (student A) who can remember alphabetical sign language in his long-term memory, while the others (Student C, D, and E) were initially still in progress to remember half of the ASL (American sign language) which is similarly used by BISINDO (Bahasa Isyarat Indonesia) as their mother tongue sign language. Specifically, for student $B$, he had not recognized some of the ASL yet. He needed extra time for internal intervention every meeting, and the teacher confirmed that it took time, but it was better than nothing. She was in struggling to help the student, at least keep staying in the class while learning process conducted.

\subsection{Questionnaire List Results of Deaf and Hard Hearing Students' Motivation in Learning English}

The data obtained was initially begun by recognizing students' characteristics. Based on the classroom observation and supported by the teacher's information, most of the students' characters were friendly, patient, and polite. In some cases, student B is sometimes ignorant, easy to be bored and often unpredictable, student $C$ is silent and directly nervous, and panic, students $\mathrm{D}$ is full of expression and energetic, and students $\mathrm{E}$ is silent and almost unpredictable all the time. In terms of students, motivation teacher was conducted using the interview sheet with 20 questions. However, to find the appropriate answer, the teacher privately asked the students one by one by sign language.

Table 1. Students' Motivation before Intervention

\begin{tabular}{|c|c|c|c|c|c|c|}
\hline No & Statements/ Factors making a big effort & S.A. & S.B. & S.C. & S.D. & S.E. \\
\hline 1 & Liking English subject & 1 & 1 & 1 & 1 & 1 \\
\hline 2 & Liking the teacher & 3 & 3 & 3 & 3 & 3 \\
\hline 3 & Getting high mark for some work & 3 & 1 & 3 & 3 & 3 \\
\hline 4 & Being with classmates, I like & 3 & 1 & 3 & 3 & 3 \\
\hline 5 & Being interested in the topic of the lesson & 1 & 1 & 3 & 3 & 3 \\
\hline 6 & Receiving praise & 1 & 1 & 3 & 3 & 3 \\
\hline 7 & Feeling happy & 1 & 3 & 3 & 3 & 3 \\
\hline 8 & Seeing other people doing better than me & 2 & 2 & 1 & 1 & 1 \\
\hline 9 & Working in group & 2 & 2 & 1 & 1 & 1 \\
\hline 10 & Working in pair & 3 & 3 & 1 & 3 & 3 \\
\hline 11 & Finding the work easy & 3 & 3 & 3 & 3 & 3 \\
\hline 12 & Feeling uncomfortable, such as too hot or cold & 2 & 2 & 2 & 2 & 2 \\
\hline 13 & Feeling confident that I can do something & 2 & 2 & 1 & 2 & 2 \\
\hline 14 & Thinking the teacher is interested in me & 1 & 3 & 3 & 3 & 3 \\
\hline 15 & Having clear goals for the lesson & 1 & 1 & 1 & 2 & 2 \\
\hline 16 & $\begin{array}{l}\text { Having clear rules about how we work } \\
\text { together in the class }\end{array}$ & 1 & 1 & 1 & 2 & 2 \\
\hline 17 & Sitting still for a long time & 2 & 2 & 2 & 2 & 2 \\
\hline 18 & Being in bad mood & 2 & 1 & 2 & 1 & 1 \\
\hline 19 & Feeling that I have some choice in what I do & 3 & 1 & 3 & 2 & 2 \\
\hline 20 & Feeling the media is important & 3 & 3 & 3 & 3 & 3 \\
\hline
\end{tabular}


After doing some interventions, then at the end of the English meeting class, the researcher asked the teacher to interview the students by using a similar interview sheet relates to the students' motivation in learning English. The following table 3, shows the result of data.

Table 3. Students' Motivation after Intervention

\begin{tabular}{|c|c|c|c|c|c|c|}
\hline No & Statements/ Factors making a big effort & S.A. & S.B. & S.C. & S.D. & S.E \\
\hline 1 & Liking English subject & 3 & 3 & 3 & 3 & 3 \\
\hline 2 & Liking the teacher & 3 & 3 & 3 & 3 & 3 \\
\hline 3 & Getting high mark for some work & 3 & 1 & 3 & 3 & 3 \\
\hline 4 & Being with classmates I like & 3 & 1 & 3 & 3 & 3 \\
\hline 5 & Being interested in the topic of lesson & 3 & 3 & 3 & 3 & 3 \\
\hline 6 & Receiving praise & 1 & 3 & 3 & 3 & 3 \\
\hline 7 & Feeling happy & 3 & 3 & 3 & 3 & 3 \\
\hline 8 & Seeing other people doing better than me & 3 & 2 & 3 & 3 & 3 \\
\hline 9 & Working in group & 1 & 2 & 1 & 1 & 1 \\
\hline 10 & Working in pair & 3 & 3 & 3 & 3 & 3 \\
\hline 11 & Finding the work easy & 3 & 3 & 3 & 3 & 3 \\
\hline 12 & Feeling uncomfortable, such as too hot or cold & 2 & 2 & 2 & 2 & 2 \\
\hline 13 & Feeling confident that I can do something & 2 & 2 & 1 & 3 & 2 \\
\hline 14 & Thinking the teacher is interested in me & 3 & 3 & 3 & 3 & 3 \\
\hline 15 & Having clear goals for the lesson & 1 & 1 & 1 & 1 & 1 \\
\hline 16 & $\begin{array}{l}\text { Having clear rules about how we work } \\
\text { together in the class }\end{array}$ & 1 & 1 & 1 & 1 & 2 \\
\hline 17 & Sitting still for a long time & 3 & 3 & 3 & 3 & 3 \\
\hline 18 & Being in bad mood & 2 & 1 & 2 & 1 & 1 \\
\hline 19 & Feeling that I have some choice in what I do & 3 & 1 & 3 & 3 & 1 \\
\hline 20 & Feeling the media is important & 3 & 3 & 3 & 3 & 3 \\
\hline
\end{tabular}

The table above shows significant differences for some items; number 1, 6, 12, $13,16,17$, and 18, especially how the students like English and feeling happier, more confident in doing a task in English. They were also excited working in pairs and accomplished the challenges given during sequences interventions.

\subsection{Observation Result}

During this phase, the class interaction was treated and scaffolded by flashcards, face to face lip reading and using the mirror, instruction by ASL spelling, matching section in pair, and competition, individual tasks to accomplish, and creating their flashcard. Their memorization helped by visual aids, included of their own ASL poster display and mini-poster and pictures from flashcards and tablet. This phase also determined how students' motivation gained by the teaching media and to what extent the media can encourage students to enrich their vocabulary, as well as for increasing their basic language aptitude.

The following elaboration shows the students' progress from the beginning until the end of meeting in terms of how the explanation and intervention from teacher affected students' direction, attention, conflict, and performance. 
Student A initially followed a few directions/ rules and needed 3-4 corrective measures. However, the progress showed that in the end, he followed directions/rules. He did not take any corrective measures. It means that student $\mathrm{A}$ has good memorization that he could directly remember the words, spelled it by ASL, and wrote it correctly. In his attention, he wandered physically/mentally, and instruction(s) sometimes needed to be repeated. In the conflict phase, the student got along well with the others and was flexible. He made a conscious effort to avoid being disruptive. After treatment, he still got along well with the others and was congenial. He followed directions and did not disrupt the class. In terms of his performance, firstly student's work was reflective of his abilities and effort, and finally, his work ethic exemplary. He put in extra effort to do well. It showed by how he helped his other friends to remember the vocabulary and elicit them to show the best performances in the class.

Student B has double handicapped. Based on the observation, when he was given instruction, the student did not follow directions and rules. He needed more than five corrective measures. After treatment, he followed most directions/ rules. Then he needed only 1-2 corrective measures. In his attention, student B in 3 meetings did not pay attention at all in the classroom. Instructions needed to be repeated frequently. However, at the end of this research intervention, he paid attention in class and stayed on task, while the previous days, he is the only one who wanted to earlier go home after break, sometimes doing nothing in English class except only isolating himself by sitting in the classroom and dictating simple word without taking into a part of the class activities. In terms of conflict, he did not get along with others. He was argumentative and defensive. He was very silent; in consequence, the teacher did not understand his mood and his willing. For his performance, initially, his effort was inconsistent. He tried to get around doing assigned work, and then after the intervention, his work was reflective of his abilities and effort. The student was asked by the teacher and assisted by his parents to bring some mini-posters and do some regular tasks using flashcards intensively done at home and school. Ultimately, he could remember every single word, spell the ASL correctly, and accomplish his portfolio tasks.

Student C, D, and E were almost equal in their observation. At the beginning of the meeting, using media, they felt happy showing their photos displayed in a poster. Both of them attempted to memorize and repeat the spelling of ASL and numbers regularly. In terms of the rules, student $C$ followed a few directions and needed 3-4 corrective measures, while student $\mathrm{D}$ and student $\mathrm{E}$ did not follow directions. They needed $5+$ corrective measures.

Nevertheless, after the intervention, student $C$ and $D$ followed the rules and did not need any corrective feedback. Whereas student $\mathrm{E}$ followed the most direction but still needed 3-4 corrective measures. In their attention, they paid attention in class but needed more complicated tasks clarified. They were only usually on task. However, at the end of the research meeting, student $C$ and D paid attention to the task and stay finishing the portfolio. Meanwhile, student E did not accomplish the task since he did not come at the end of the research assessment.

The conflict did not occur for both of the students C and D. They only depend on the parent's help to make them being punctual and going to school. Student $C$, as he told the researcher, had much housework in her home, and then she would absence 
for some meetings. Students D also had a similar problem. He would be depended on his busy parents who picked him up to go to school. As well as student E, he also had a conflict with himself since he did not fully join the intervention because of his absence in several meetings. In the last terms, performance, students C, D, and E had equal progress. Initially, they did not put forth the quality effort and made many mistakes and excuses. Furthermore, at the end of the research process, they reached the part of students' work was reflective of their abilities and effort to memorize, recognize, and do the task. Students' diverse characteristics need more effort from teachers and parents also people around them to learn by doing and by heart.

Motivation can directly help them to increase their language aptitude. The interview shows the result. The first assessment method was chosen to collect data by questionnaire to collect information. Further, the second assessment can be obtained by observation. From the result shown, students really enjoyed the class activities and interested in English class, and it affected their motivation, and the vocabulary turned to develop.

Displaying posters for the first time were very helpful to attract student attention. It can build their confidence as the starting point of their learning ASL. They displayed the colorful alphabet and created visual material as much as possible. It is in line with the suggestion that a very crucial thing and significantly used effective and suitable for deaf students was using pictures and posters (Davis, 2000). In addition, visual aids are for visual learners, determining on focusing on what students can do, setting up a positive language experience, breaking down the tittles into small parts, using multiple examples, using different colors to attract students' attention, trying computer-assisted language learning program and making use of cognates. Flashcard used visual aids suitable for deaf students.

For students' motivation, the results of the questionnaire showed that all of the students felt the intrinsic motivation, which maintained students' curiosity handling the task and memorizing new words. It was in line with Ellis (1997), who states that motivation is maintained by the curiosity and the learner's particular interests that keep them personally involved in the learning process. Besides, they were also encouraged by a result of motivation observation 1 , which is shown by their successful and feeling happy when they have finished the challenges.

\section{Conclusion}

The process of acquisition and learning language should emphasize repetition, diverse activities, and challenging. It is known that deaf and hard hearing students have impairments in recognizing new vocabulary. They sometimes feel uncomfortable with the fast lips reading and directly easy to forget something. Then appropriate strategies can be used to cope with students' needs. Flashcards have been proved as evidence to improve students' motivation in EFL classes. They can be modified and used depending on the student's needs. Teacher efforts and availability of media used in learning will contribute to the success of teaching and learning process, especially for special needs students. In addition, the people surrounding them, such as proficient teachers, parents support, and friends, will be very helpful for increasing special students' language aptitude development. Findings in this study apply to real-world learning situations because deaf people do not always have a chance to encounter visuals while learning vocabulary during their own lives. There should be some other techniques 
that can be implemented. Therefore, they also should be encouraged to develop their learning strategies, which they can use in their real lives. Furthermore, in this study, learners at the beginner level were investigated. For further studies about using visual materials and sign language, different levels and ages might be investigated. Moreover, the scope of this study was only on vocabulary, then, visual materials can also be used in teaching other language skills such as writing, reading, grammar, etc.

Acknowledgments

This research was supported by LP2M IAIN Kendari and students, teacher and specially Headmaster of SLB-F Mandara Kendari. We also thank our colleagues from IAIN Kendari and the reviewer of Litabdimas Kemenag RI, who provided insight and expertise that greatly assisted the research process.

\section{References}

Cheon, S. H., and Reeve, J. (2015). A classroom-based intervention to help teachers decrease students' motivation. Journal of Contemporary Educational Psychology 1 (40), pp. 99-101.

Davis, C.D. (2000). Foreign language instruction: tips for accommodating deaf and hardhearing and deaf students. Washington DC: Western Oregon University Press.

Dolorosa, S. V. (2016). Buku guru bahasa inggris tunarungu, buku bahasa inggris kurikulum 2013. Jakarta: Kemendikbud.

Ellis, R. (1997). Second Language Acquisition. Oxford: Oxford University Press.

Ghafoor, M. A. A. \& Huang, J.Y. (2015). Survey on the use of application for deaf and hard hearing literacy. Presented in international conferences on computer, communication and control technology in Malaysia.

Hasstenteufel, P. (2009). The English language production of a deaf student - a case study. Journal Signos Ano 2, p. 71

Herrera-Fernandez, V. et al. (2014). Visual learning strategies to promote literacy skills in prelingually deaf readers. Sistema de Información Científica 10 (1), p. 3.

Saripah, W. \& Syukri, S. (2017). Improving student's motivation through a short stories in learning English. Alta'dib jurnal kajian ilmu kependidikan 10(2), pp. 109-126.

Lazanova, S. \& Savtchev, B. (2009). Analysis of needs, constraints, practices, and challenges to the deaf and hard hearing impaired learners of languages. Preliminary research. Deaf port project.

Lichtert, et al. (2016) Diversity in deafeducation: high standard competencies for teachers of the deaf and other qualified professionals: always necessary not always guaranteed. United States of America: Oxford University Press.

Mpofu, J. \& Chimhenga, S. (2013). Challenges faced by hearing impaired pupils in learning: a case study of King George VI memorial school. Journal of Research $\mathcal{E}$ Method in Education 2(1), p.71. 
National Council Accreditation of Teacher Education (2006). What makes teachers effective?http://www.ncate.org/dotnetnuke/LinkClick.aspx?fileticket=JFRrm Wqa1jU\%3D\&tabid=361.

Nunan, D. (1992). Research Methods in Language Learning. Australia: Cambridge University Press.

Razalli, A. R. et al. (2018). Using text with pictures in primary school to improve reading comprehension for hearing impaired students. Presented in International conference on special education in Southeast Asia region in Malaysia.

Sass- Lehrer, M. and Young, A. (2016). Diversity in deaf education: evidence-based practice in early intervention: the proof of the pudding is in the eating. United States of America: Oxford University Press.

Stinson, M. S., Lisa, B. Elliot, and Kelly, R.R. (2017). Deaf of hard-hearing high school and college students' perceptions of speech to text and interpreting/note taking service and motivation. Journal of development physical disabilities, 29, pp. 131-152.

Weller, M. (2005). Motivation. Los Angeles Business Journal. p.1.

Williams, Marion, Sarah, M., \& Ryan, S. (2015). Exploring Psychology in Language Learning and Teaching. Oxford: Oxford University Press. 